\title{
Taking Asia Seriously
}

\author{
Martin Griffiths \\ Griffith University \\ Michael Wesley \\ The Lowy Institute for International Policy
}

\begin{abstract}
Australia has traditionally relied on two diplomatic strategies in its attempts to 'engage' Asia. The first has been to couch engagement diplomacy within broader global trends and developments, such as the response to the Communist threat during the Cold War or the general move towards the 'new regionalism' after the Cold War. The second strategy has been a dogged prudentialism, building on shared (usually commercial) interests. The shortcomings of both strategies became apparent in the lead-up to the 2005 East Asia Summit, where Australia faced a diplomatic exclusion not as the specific policy choice of another country, but as the unintended byproduct of rivalries among Asia's great powers. That the success or otherwise of Australia's regional engagement will be shaped by such rivalries in future was reinforced by the sensitivities aroused over the Prime Minister's trip to China in 2008. Perhaps the bigger lesson is that Asia's rivalries are no longer sub-sets of global dynamics. We may be entering an era in which Asia's rivalries drive broader global dynamics, which in turn will pose severe challenges for Australia's regional diplomacy.
\end{abstract}

\section{Introduction}

'Engagement' seems to be the indispensable word when it comes to describing Australia's relations with the states of East Asia. Its (over)use derives from its fuzziness. 'Engagement' connotes sustained attention and positive intentions; it describes diplomacy as well as economic, social and even cultural relations; it is a blanket term that can be thrown over long swathes of diplomatic history and allow missteps, triumphs, failures, and changed directions to be described as basically bipartisan. Moreover, it can mollify those keen for full integration with Asian institutions as well as those suspicious about the 'Asianisation' of Australia. 'Engagement' speaks of earnest commitment to a relationship while leaving vague all talk of marriage. The term refers to process, not destination. Substantive discussion of the latter is politically risky. It would invite critics both at home and abroad. Talk of a union, a community or a bloc between Australia and Asian states generates a host of unresolved agendas: what will this mean for our relationship with the United States? Is there a surreptitious cultural agenda to 'Asianise' Australia? What will our association with semi- and non-democratic states mean for our political ideals? Similarly voices from the region will question Australia's commitment to the primacy of its Asian relationships; whether by seeking closer union Canberra is seeking to 
dilute Asian regionalism and whether Australia can really accept 'Asian' diplomatic practices and regional priorities.

In this article we make three arguments. First, we trace the historical evolution of Australia's regional diplomacy, which we claim must be understood in the context of changes at the global level and how these changes have been interpreted in Canberra in terms of their impact on Australian security and prosperity. Second, we argue that there are powerful political pressures (both in Australia and from the region) which encourage Australian policymakers to pursue and justify their regional diplomacy in prudential terms, emphasising the short term benefits of particular policy initiatives to the 'national interest'. Finally, we explore the limits of this approach in light of contemporary changes in the global balance of power and the resultant fragility of international institutions. There are unprecedented challenges in the near-to-medium term, which will call for more than just pragmatic policy management, and make it extremely difficult to pursue a policy of engagement through the traditional route of middle power multilateralism.

\section{The Global Logic of Regionalism}

Perhaps the most distinctive feature of Australian foreign policy is the consistency with which such a modest power has focused on global stability and power configurations (Gorgao 2003, 179). Australia's isolation and its early identification with the British Empire have given rise to a foreign policy culture that takes it as read that changes to the global distribution of power and global stability, however distant, will eventually affect Australia's security and prosperity. Australian troops since the 1880s have travelled abroad to defend the strategic position of the Empire and the West. Australia subscribed to Britain's grand strategic imperatives: maintaining the Empire, the supremacy of the Royal Navy, and the balance of power in Europe. The disturbance of any of these would be a threat to Australia, as shown before the First World War when Germany's power was translated into a naval presence in the Pacific (Robertson 1988; Grey 1999).

\section{The Cold War and Regional Engagement}

After the end of the Second World War, Australia was confronted by the regional implications of decolonisation. There was a sense in Canberra that the process could not be stopped and that new post-colonial states to its north would present Australia with a range of challenges. As C. P. Fitzgerald $(1957,10)$ put it:

The official Australian attitude to the New Asia can be defined as composed on one hope and two fears; the hope that nationalism, with which most Australians sympathise, will bring order and peace to the newly independent nations of Asia; the new fear that Communism will outpace nationalism in the race for these peoples' allegiance; and the old fear of Japan'.

There was an early recognition that Canberra would have to forge ties with these countries without relying on the old Empire connections which rankled post-colonial elites. Very quickly, however, Australia's engagement was dominated by its integration into the broader struggle against communism. In 1949, a localised and 
apparently more malevolent strain of Communism had infected Asia's largest country. By the following year, Australian troops were fighting alongside western allies against a communist alliance in the first hot war of the Cold War on the Korean peninsula. In the years after, Diggers were sent to battle communist insurgents in the jungles of Malaya and Vietnam.

Initially, British Empire links directed most of Canberra's attention to members of the new Commonwealth of Nations: India, Pakistan, Ceylon (soon to become Sri Lanka), and later Malaysia and Singapore. But as the Cold War deepened, this policy lost its appeal. Australia was faced with a choice that would shape its postwar foreign and security policies, between joining an emerging pan-Asian regional solidarity that gained expression at Bandung in 1955, and fitting into a rigid, hub-andspokes security architecture centred on the United States to contain communism. The choice was obvious. The United States' response to the Korean War reassured Australians that, having defeated Japan, Washington continued to be willing to invest heavily in countering security threats in the Pacific region. Australia voted at the United Nations to condemn China's aggression in the Korean War in February 1951, setting it apart from Commonwealth states such as India. The Menzies government shelved Foreign Minister Richard Casey's plan to broaden ANZUS into a regional framework including Asian states and Britain, and by November 1953 Casey told Parliament that 'under present circumstances no recognition of Communist China or admission of its representatives to the United Nations would be entertained' (Casey 1953, 664).

Australia had identified its national security with American definitions and defences of regional and global order. This was to provide uncomfortable moments for Canberra. The dilemma over Taiwan occurred in the 1950s, when the Eisenhower administration announced its 'deneutralisation' policy and stated its support for the Taipei regime. Emboldened by American support, the regime in Taiwan began raids on the mainland that rapidly escalated into the first Formosa crisis. The Australian Cabinet held tense discussions over what to do if war broke out between Beijing and Washington over a regime that Australia had withdrawn recognition from a few years previously. Even more jarring for Australian policymakers was Dulles' statement after the first crisis that Formosa was as important as South Korea, the Philippines, New Zealand and Australia - a clear signal of Washington's expectation that conflict in the Taiwan Straits would trigger ANZUS obligations. The consolidation of communist power in northern Indochina following the 1954 Geneva Accords led to the Australian government stationing forces in Malaya, and to Canberra's participation in American designs to develop an Asian NATO in the form of SEATO. Both moves amounted to a break from Asian solidarity symbolised by Bandung. By the early 1960s, Canberra was convinced that Australia had chosen correctly. The solidarity of Bandung had proved either ephemeral or malevolent. Two of the leaders of the Non-Aligned Movement, India and China, had fought a border war in 1962, and Sino-Indian relations thereafter descended into a cycle of hostility and intrigue. The host at Bandung, Indonesia's President Sukarno, had turned his relationship with Beijing into Chinese support for his policy of Konfrontasi against neighbouring Malaya. Australian opinion saw both incidents as evidence of the aggressive nature of Chinese communism, the only defence against which was participation in an American-led campaign of containment in Asia. 
The discordant note in Australia's commitment to the western alliance was trade. By the late 1960s, Australia's most important trading partner had become Japan, the main focus of its apprehensions in the post-war period and the major rationale for its push for a formal alliance with the United States. In addition, since 1949, and throughout a period in which Australian troops had been fighting Chinese or Chinese-backed forces, Australia had been conducting a brisk commodities trade with a country whose government it refused to recognise. By 1961, China displaced the United Kingdom as the principal market for Australian wheat, and in the ensuing decade bought between 30 and 40 per cent of the Australian harvest. In 1967, Australia became the third largest supplier of goods to China, behind Japan and West Germany. By then, Australia's only deference to Washington's trading embargo against China was to observe the embargo on 'strategic materials'.

By the 1970s, the ideological rigidities of the Cold War in Asia had given way to a complex balance of power. In Hedley Bull's words, 'the ideological professions of each [of the great powers] provided less and less of an inhibition to its mobility in foreign policy’ (Bull 1974, 325). By early 1970, Opposition leader Gough Whitlam was arguing that even Washington had moved ahead of Canberra on the question of China, and in July 1971 took the politically risky decision to lead an ALP delegation to China. The announcement that same month that United States National Security Adviser Henry Kissinger had also visited China and had laid plans for President Nixon's visit pulled the carpet from under the government in Canberra. Whitlam led the ALP to victory in the 1972 elections after 23 years in opposition. One of the new government's first actions was to establish diplomatic relations with China and remove recognition from Taiwan, with which it had exchanged Ambassadors in 1966. The new pragmatism in Australian foreign policy in Asia saw Canberra enter the Five Power Defence Arrangements with Malaysia, Singapore, New Zealand and the United Kingdom, and establish dialogue status with the consolidating Association of Southeast Asian Nations.

\section{Australia and the 'New Regionalism'}

Two events occurred in the early 1970s to challenge Australia's conception of its security and prosperity in a global context. On 1 January 1973 the United Kingdom formally became a member of the European Economic Community. Even though Australia's trade patterns had been regionalising for over a decade, Britain's entry into the EEC symbolised a formal end to Australia's century-and-a-half era of economic security within the bounds of the British Empire's Imperial Trading Preference arrangement. Then on 17 October of the same year, Arab oil producers instituted an oil embargo against western countries, bringing an end to post-war economic expansion. As the world economy entered recession and 'stagflation', Australia's decline in growth, and its unemployment and inflation levels were among the worst in the OECD in absolute terms, and in comparison with its own past economic performance. A consensus formed around a new policy orthodoxy: in order to restore productivity to enable Australia's economy and society to respond to the international economic environment, the 'dead hand' of government and vested interests had to be lifted from the market, and the forces of competition had to be introduced (Conley 2002, 384). 
Trade became a prominent theme in Australian foreign policy. As Australia underwent neoliberal economic reforms at home, it became a champion of economic reform globally. The decline in world commodity markets had hit Australia hard, and Canberra became an opponent of the use of agricultural subsidies by the EEC and the United States. The states that were taking an increasing proportion of Australia's exports were also the miracle economies of this period. The East Asian economic 'miracle' provided a positive model for Australia of the benefits of trade-driven development. An early initiative was to assemble the Cairns Group of Fair Agricultural Traders in Cairns in August 1986 to press Americans and Europeans into including agriculture on the agenda for global trade talks. Asian industrialisation created markets for Australian commodities exports. Australia soon established healthy trade surpluses with Western Pacific countries, and by the late 1980s the majority of Australia's trade was with this region. The Garnaut Report (1989) was a compelling argument that trade diplomacy must assume a regional focus. The desire to protect this complementarity through a regional trade structure had long been discussed around the Pacific Rim, and was felt within Australia's foreign policy establishment (Soesastro 1994). But there were less positive imperatives that also suggested the need for a new regional structure. First, trade figures emerged in the late 1980s suggesting that while exports to East Asia were expanding, Australia's market share in the region was declining, most disturbingly in agriculture (Drysdale and Lu 1996). Second, by the late 1980s, the global trading system appeared to be in trouble. The Uruguay Round negotiations was experiencing difficulties, while regionalism seemed on the rise with the signing of the Single European Act (SEA) and the North American Free Trade Agreement (NAFTA). Australian policy makers became concerned about the rise of blocs - none of which it was a natural member - as well as the enduring acrimony between the United States and Japan. A permanent break between these powers - one Australia's most important military ally, the other its most important trade partner - was an unpalatable choice. Third, a regional free trade structure would allow the government to address rural demands and stabilise expectations and moderate domestic perceptions of the risks of trade liberalisation (Garnaut 1999, 15).

In seeking a regional trade structure, Australia played a decisive role in the founding of the Asia Pacific Economic Co-operation (APEC) forum, whose first meeting was held in Canberra in November 1989. APEC gave expression to Australia's vision of its region: it included the countries of the Pacific littoral, but not the states in the middle of the Pacific Ocean or those of South Asia. The justification was largely economic - APEC included the key economies in a dynamic trading cycle: Japanese industry and investment, East and Southeast Asian low-cost manufacture, voracious North American markets - and Australian commodities. APEC also allowed Australia to reconcile the potential tensions in its regional relations. While Australia's identity as an Asian country was controversial in both Australia and Asia, there is no disputing that it is a part of the Asia Pacific littoral. The Asia Pacific definition allowed Australia to reconcile its commitment to the United States as well as Asia's booming economies. When in 1990 Malaysian Prime Minister Mahathir proposed an alternate grouping of the states of East Asia, Canberra lobbied against it, seeing it as a threat to the Asia Pacific definition of the region and to Australia's integration with Asia's dynamic economies. By 1994, Australia was a strong supporter of the creation of the ASEAN Regional Forum, a cooperative 
security institution that more or less borrowed APEC's definitions of the region's boundaries.

\section{Prudential Regionalism}

Few countries confront such differences in culture and wealth with their region than Australia, and consequently Australia's relations with Asian states have deep resonances for the self-perception of Australian society. Australia's regional relations have always been imbued with a domestic political significance. The perception of difference from Asia - demonstrated by the tendency to lump together so culturally diverse a region into 'Asia' - has presented Australian governments with domestic political challenges as a counterpart to their diplomacy. The initial response of Australian governments was elitist: to forge Australia's regional diplomacy above the electorate, presenting Australians with a string of faits accomplis that they would hopefully come to accept. Governments on both sides of politics believed that regional relations required changing social attitudes at home. Diplomacy was expected to lead public opinion. This was the logic of the Menzies government's signing of the 1957 trade agreement with Japan, and the Fraser government's decision to accept Vietnamese refugees in the 1970s.

Ultimately, this approach politicised Australia's relations with the Asian region. The region became a symbol of change in Australian society, with those believing passionately in the need for change becoming partisans for enmeshment with Asia (see, for example, Fitzgerald 1997). Their opponents were a diverse and shifting coalition on the right and left. Indonesia's invasion of East Timor in 1975 had given birth to a body of opinion on the left that challenged Australia's pragmatic relationships with brutal and dictatorial regimes. It was joined by those who feared the 'Asianisation' of Australian society through immigration.

The domestic controversies aroused by Australia's regional engagement led governments from Hawke to Howard to couch Australia-Asia relations in narrow, prudential terms. It was a chain of reasoning that ran through the Garnaut Report. Australia was engaging with Asia because it was in Australia's interests to do so. Economic self-interest was presented as the driving motor of engagement. Even Paul Keating and Gareth Evans' 'big picture' visions of regional association were based on the economic logic of trade cycles, trade blocs and the dangers of exclusion from Asian markets. This logic emerged emphatically in the Howard government's pragmatic bilateralism in the region. Howard's preferred formula for dealing with Asian states was based on 'mutual respect' and 'shared interests'. For Howard, none of the Labor Party's regionalist casuistry could bridge the gap in values, culture and history between Australia and its Asian neighbours. This does not mean that Australia was uninterested in the fate of the region's societies. Repeatedly, the Howard government assisted Asian countries in crisis, both financial and natural. But in all justifications of Australian assistance, there was always a strong undertone of our self-interest in stable and prosperous societies in the region. Consequently, concrete destinations of 'engaging with Asia' are usually discussed in negative terms: as models of what not to do (such as replicate the European Union) or as states of affairs to be avoided. Engagement thus precludes destabilising competition, economic instability; and ensuring that no regional bloc develops to exclude Australia from its primary markets. The political contexts that attend Australia's regional relations make 
it almost impossible to agree on and discuss explicitly a destination for Canberra's regional diplomacy. The need to fall back on process goals exercises a powerful shaping role on the style and techniques of Australian diplomacy. It also brings with it, however, dangers of policy myopia, a tendency to concentrate on getting the immediate policy pragmatics right, at the expense of thinking through their long-term implications.

In addition to the domestic constraints on 'Asian engagement', Australia's regional diplomacy is limited by suspicion among specific Asian states about the motivation and consequences of regional activism from Canberra. For example, many practitioners and academics of Australian foreign policy would argue that Australia has been extremely creative in its regional diplomacy over the past two decades. Canberra's efforts in driving forward APEC, the ASEAN Regional Forum, and more recently the AP-6, it could be argued, reflect a foreign policy far-sightedness that few countries could boast. However, it is possible that our activism in constructing institutions may also be a manifestation of foreign policy opportunism. The act of putting in place an institution busies diplomats and commentators with the minutiae of practicalities, while crowding out time for consideration of the objectives the institutions are designed to achieve. As a result, Canberra has sometimes been surprised when the institutions it creates lead to unexpected and negative results. A good example came with the creation of APEC in 1989, an institution designed to forestall the fracturing of trade and diplomatic relations between East Asia and the United States. What APEC's architects did not expect was a reaction in the form of Mahathir's East Asian Economic Caucus, which would threaten to bring about the situation APEC was created to avoid: a divide between East Asia and North America and Australia's exclusion from a region on which it was economically reliant. Mahathir exploited post-colonial grievance and Asian success to assert that Asian countries do not need Western advice about how to develop or organise their own politics (see Langlois 2001). 'Asianism' focuses on beliefs that the era of Western ascendancy is coming to an end, that the future belongs to Asia. It expresses convictions that a lack of solidarity among Asian states allows outside powers to play a dominant role in the region, that as long as Asian countries' ties to external states are stronger than their ties with each other this will continue, and that only genuine solidarity can Asia play a central role in global politics. These themes resonate among many in Asian countries, and the incentive to draw on them has been a constant in regional politics.

\section{The Emerging Policy Environment}

Since its European colonisation, Australia has always been a status quo power. Born a member of the most powerful Empire of the time, it shifted into intimate alliance with a new, culturally similar superpower when the British Empire began to fray. By its very nature, a status quo power seeks to manage adverse change. It is a highly riskaverse state, which is sensitive to developments that could degrade its position of comfort and privilege. Other factors reinforce Canberra's foreign policy pragmatism. One is cultural, born of a national character that is suspicious of big, abstract thinking and likes immediate, observable results. Another is bureaucratic, a function of executive overload. Foreign policy making in Australia is done by a select few who are also attentive to the day-to-day management of the political cycle. Major foreign policy decisions are made with careful assessment of their immediate effects on the 
short-term media cycle and the resulting political implications (see Gyngell and Wesley 2007). One final factor might be called a 'culture of serendipity' that infects much thinking about Australia's place in the world. When, in 1942, the Japanese swept through Singapore and the British were tied down in North Africa, the Americans appeared. Just five years before the Arab oil embargo brought Europe, Japan and the United States to their knees, Australia had become over $70 \%$ selfsufficient in oil due to the discovery of the Bass Strait oil fields (Morse 1988, 748). And much of the subsequent economic shock was mitigated by Japan's switch from oil-powered electricity generation to coal-fired and nuclear-powered plants, both of which were supplied by imports from Australia. A country that has never had to weather the full impact of an international challenge is not disposed to think hard about the future (Horne 1965).

Over the last two decades the East Asian region has done well economically, but it is faced with uncertainties. The role of the United States has been the anchor of stability since Second World War while bilateral alliances-especially the US-Japan alliance-have been the main instrument for the US presence and are still in place (thanks to the Seventh Fleet). Nonetheless, the United States as the only global superpower has declined in relative terms. Moreover, over the past five years the United States has been diverted by conflicts in the Middle East and Central Asia (especially Iraq and Afghanistan) and developments there remain fluid. In the meantime, the region has seen new strategic developments and challenges for Australia.

The most important element is the rise of China. Thus far, this rise has been peaceful. Another strategic issue is the normalisation of China-Japan relations. But the most important issue for the region will be the future relationship between China and the United States. How they relate to each other will determine the state of affairs in East Asia and shape the regional context for Australian foreign policy. If East Asia continues to grow with Japan, China, and India driving its development, it will indeed become the most important region of the globe and the balance of power will certainly shift over the next few decades, first in the economic sphere (trade among East Asian economies now represents over half of the region's total trade, which is almost equal to intra-EU trade and already higher than intra-NAFTA trade), then in the political field, and possibly also in the security field. But there is nothing inexorable about the sequence, or benign consequence, of that shift. The end of the nineteenth century and the beginning of the twentieth century showed that economic growth and dynamism alone were not adequate to create peace and stability in Europe. The relationship between a rising power and an established one, such as that between China and the United States, is never an easy one. In order for this shift in the balance of power to take place peacefully in East Asia, two things have to happen. First, the shift must occur gradually and should not be considered a zero-sum game by the established powers. Second, emerging powers in East Asia should prepare themselves to adapt. That means not only sharing power but also responsibility (Bergsten 2008, 68). China, for instance, needs to understand that its relations with states such as Iran, Sudan, and Myanmar will be viewed in light of its international obligations and its new role.

Another equally challenging development for a 'middle power' like Australia is the second big trend is the creeping crisis of international institutions. The multilateral era, dating from the end of the Second World War, holds two key lessons 
for thinking about the polarity mediation capacities of international institutions. Over the course of half a century of polarity transitions -from multipolar to bipolar to unipolar and once again to multipolar - it has proved extraordinarily difficult to reform the decision making systems of major institutions to reflect power shifts. This has not affected the endurance of these institutions, which by and large have persisted despite the declining relevance of their representational structures. The continued construction of multilateral fora, both regional and global, partly reflects calculations that it is easier to set up new bodies than to reform or scrap existing ones. But this is not a perennial solution, because as the international stage becomes increasingly cluttered with institutions, there is less room for new inventions.

There are several reasons for institutional sclerosis. Proposals for institutional reform often run into a form of perceptual parochialism, in which influential states within an organisation privilege short-term relative status considerations over longer term considerations of the institution's relevance and effectiveness. Often opponents of reform raise general considerations such as the dilution of decision making effectiveness, or specific concerns about the suitability of certain candidates to be granted more responsibility, but it is hard to ignore their underlying interest in preserving relative status. Those states that have gained relatively powerful positions at the outset tend to jealously guard their prerogatives against reform attempts that would maintain the institution's relevance to its evolving environment. This is particularly the case for powers on the wane or challenged by rising rival powers, which often rely on the structural power conferred by a privileged place in an institution to bolster their waning influence.

The paucity of structural reform of existing international institutions is matched by the rarity of the disestablishment of organisations no longer thought to be relevant or effective. There are several barriers to organisational renovation. Institutions are prey to what may be called an effectiveness trap, whereby an organisation, by contributing to a certain positive state of affairs internationally, comes to be seen as essential to those outcomes. This gives rise to a reluctance to jeopardise those outcomes, even if they are thought to be suboptimal, in the cause of risky experiments with institutional renovation. The case of the nuclear nonproliferation treaty is a case in point. Despite the deep malaise that affects that regime, there is a fear that its scrapping would lead to a rise in proliferation, even though there is little evidence that the treaty has played a decisive role in restraining proliferation for the past several decades (Wesley 2005).

A related cause of 'reform reluctance' is the belief that institutions are the product of specific windows of opportunity, and embody significant diplomatic 'sunk costs'; therefore to abolish one institution without a guarantee of an improved replacement is foolhardy. Also, most institutions are formed around visions of progress and commitments to solidarity in international relations; consequently there are high symbolic costs attached to the abandonment of such organisations. Finally, institutions shape their members' incentives and interests. The older the institution, the greater the sense of ownership felt by its member states, many of which see vital national interests tied up in its continued functioning.

As new powers arise, or as new issues prioritise different combinations of states, it is easier to set up new institutions than to reform or abandon existing ones. 
Often newer institutions have their origins in ad hoc summitry, and gradually develop the full administrative substructures of the older institutions. Thus the G8, which brings together the world's largest economies plus Russia, has been regularised as an annual leaders' summit, whose broad agenda is determined by a rotating chair in consultation with the other members. This heavily Atlanticist institution (the G8's only non-Atlantic powers are Russia and Japan) is mirrored in the Asia Pacific by the APEC Leaders Meetings, which operate along broadly similar principles as the G8 summits.

The task of servicing the proliferating array of multilateral institutions has begun to strain the capacities of most foreign policy bureaucracies, particularly those of developing countries. Another effect is the increasing crowding of the diplomatic schedule, to the extent that finding coinciding dates for any extra ad hoc summitry has become extremely difficult, especially in Europe and the Asia Pacific. Multilateral meetings have contributed to the increasing "routinisation" of diplomacy, a development that leaves less latitude for foreign policy makers to respond to shortterm diplomatic contingencies. Consequently, while we may soon see a rise in internationalist enthusiasm, it is hard to see which institutions will best service such internationalism. The United Nations? NATO? The G8 or APEC? All are plagued with issues of membership, power and the distribution of effort internally which are not easy to reconcile. We face an international stage increasingly cluttered with international institutions that are less and less able to help manage the problems of global order.

In this context, 'engaging' with Asia cannot be equated with a dogged pursuit of multilateral organisation, particularly when the existing architecture of regional organisation remains weak (see Acharya and Goh 2007; Calder and Fukuyama 2008). Ten years have passed since the Asian economic crisis exposed the dark side of the region's growing interdependence. Since then, the region's economies have only become more interconnected, and regional leaders have embarked on a drive to build up a framework for greater regional cooperation and integration under the rubric of an East Asia community. This is not an entirely new movement; there have been a series of efforts to construct some sort of regional community since at least the 1960s. The result has been the emergence of a complex set of overlapping multilateral forums and mechanisms in the region, accompanied if not complemented by a growing web of bilateral economic agreements. The result has been two institutional tracks for regional community building: a narrow ASEAN+3 and the more expansive East Asia Summit. On the ground, though, the picture has been further complicated by the rapid proliferation of bilateral and multilateral economic partnership agreements and free trade agreements throughout the region, as well as the evolution of the Six-Party Talks into a more formal arrangement in Northeast Asia. As Gary Smith and David Lowe point out, 'the rebuilding of elements of regional cooperation...was not...through any embrace of grand ideas of regional multilateral architecture or values convergence, but in a series of issue-centred collaborations and initiatives' (Smith and Lowe 2005, 466).

Over the last decade the track record for broadly gauged multilateral forums linking the United States to the region has been mixed at best. One forum, the ASEAN Regional Forum (ARF), which involves the United States, the European Union, Russia, and 23 other countries, has become a useful discussion forum on 
regional security issues, but momentum towards the goals of its founders has been stalled by disagreements over what such an organisation should achieve. APEC, the main multilateral institution linking the United States with East Asia, has also lost its momentum. APEC has been marginalised by other organisations and its inability to play an effective role at moments of crisis. Not only does the World Trade Organisation's possession of dispute resolution mechanisms make it a much more effective agent of trade liberalisation, but APEC's invisibility during the East Asian crisis of 1997 led many to question its relevance and utility (Webber 2001). Indeed, it is noteworthy that the International Monetary Fund played a much more prominent role in crisis management and in pushing through the sort of market-oriented reforms than APEC did in the aftermath of the East Asian crisis. Perhaps the most telling indication of APEC's effectiveness is that many of its members, including the US, Australia, Japan and Singapore, have abandoned the sort of multilateral approach that APEC promotes in favour of bilateral or more narrowly conceived and discriminatory preferential trade agreements (Gyngell 2007).

Efforts to embed East Asia's powers into a stable regional order have to overcome an imposing set of obstacles. The most acute of the structural and historical obstacles involves the major powers in the region-China and Japan-which are potential rivals whose relations both with each other and with other countries in the region are tainted by lingering historical animosities (see Heazle and Knight 2007). An intensified competition for regional predominance between these two countries has the potential to unravel the gains made to date in terms of East Asia community building. Political obstacles to community building efforts are equally pressing, ranging from the difficulty in finding effective leadership for any regional collaborative project to the region's diversity in terms of political systems (Jones and Smith 2006, 221). ASEAN needs to be in the driver's seat for any regional effort because neither China nor Japan can accede to the other's leadership. But internal dynamics in ASEAN itself make this challenging (Haacke 2003). Moreover, visionary personal leadership is lacking. The region has not produced the equivalent of a Monnet or a Schumann, who so successfully advocated the creation of a European Community. Finally, socioeconomic obstacles cannot be overlooked, especially since they are connected to the structural and political obstacles. The stark differences within the region in levels of economic development (for example, between Japan and Laos) are much wider than any seen in Western Europe when it started to build a regional community. Every state in East Asia is highly sensitive to issues involving national sovereignty, even though regional cooperation is urgently needed, not only in terms of economics but also to meet the region's growing security challenges running the gamut from communicable disease and environmental degradation to terrorism and transnational crime (Dupont 2001; Burke and McDonald 2007).

Despite these problems, recent events suggest that a new surge of regionalism may be driven by growing competition among Asia's great powers. Certainly a new, China-centred East Asian regionalism has emerged since the late 1990s. This new regionalism is partly a product of a China-centred dynamic of regional economic integration. Currently approximately 58 per cent of China's exports go to other East Asian states, and approximately 47 per cent of its imports come from the region. In addition, East Asia supplies approximately 60 per cent of China's foreign direct investment, compared to 20 per cent from the United States and Europe combined (World Trade Organization 2007, 8). Furthermore, China's growth has been the single 
greatest driver of recent economic growth in the rest of East Asia. In July 2002 Beijing moved to give a formal, institutional expression to this market-led integration when it signed a framework agreement to establish a free trade area with ASEAN by 2010. As regional bodies such as APEC and the ARF gradually lost momentum, Beijing's diplomacy provided a new regional dynamism. It appeared willing to provide regional public goods, including maintaining its exchange rate during the Asian financial crisis and its 'early harvest' trade commitments to the poorer members of ASEAN.

China has become the newest convert to the doctrine of 'Asianism' - that regionalism in East Asia should be a mechanism for Asians to resist Western dominance in the region and to contest Western dominance globally (Banlaoi 2003, 103). China's exclusive regionalism manifested itself in the run-up to the East Asia Summit in Kuala Lumpur in December 2005. China's preference for the Summit was to include only ASEAN +3 states. Concerned that the Summit would increase China's regional influence at the expense of Tokyo, Japanese officials began a campaign to invite additional countries to the Summit. In putting their case, Chinese diplomats have breathed new life in the 'Asianism' that had driven earlier, Mahathirist versions of East Asian integration (see Miller 2004). Their arguments were based on the contention that East Asian countries face distinctive but common challenges in the current international order, and will only be able to respond if they are able to caucus amongst themselves, and leave behind outside commitments and considerations. The People's Daily criticised Japan for 'trying to drag countries outside this region such as Australia and India into the Community to serve as a counterbalance to China', and on his arrival in Kuala Lumpur, Chinese Premier Wen Jiabao asserted that ' $\mathrm{t}$ ] he East Asian Summit should respect the desires of East Asian countries and should be led only be East Asian countries' (quoted in Malik 2006, 4), thereby setting up an explicit contrast between China's vision of 'East Asia for the East Asians' and Japan's vision of perpetuating Western dominance of the region. The resulting Summit represented a stalemate between Beijing and Tokyo. Japan and indeed ASEAN was successful in having India, Australia and New Zealand invited to Kuala Lumpur, but China countered by inserting into the Chair's concluding statement that the ASEAN+3 grouping would be 'a vehicle for realising the dreams of forming the East Asian community'.

This episode carries worrying messages for Australia. It showed that for the first time, Australia's diplomatic interests in the East Asian region may be irreparably damaged not as the specific policy choice of another country, but as the by-product of rivalries among Asia's great powers. Perhaps the bigger lesson is that Asia's rivalries are no longer subordinate to global dynamics, rather they may be driving them. If so, then Australia's diplomatic challenge is to understand Asia's power dynamics on their own terms. New great powers that are not western, and most of them not westernaligned, are rising. As a consequence there will be a trend towards heterogeneity in the international system. The great powers will have fewer normative goals in common, and agreement on international order will coalesce around much lower common denominators: sovereignty, strict limits on the use of force and the sanctity of treaties (see Kent 2002).

The passing of the centuries-long era in which the rules, languages and institutions of international order were set exclusively by Western countries will have 
profound implications for Australia. Canberra's diplomats have always enjoyed the advantage of being able to operate internationally in a culturally familiar environment; it is their non-western counterparts who have had to learn less familiar ways of operating. And Australia will see its international significance decline as the West becomes less significant in the world. Australia stands to lose another advantage in international relations, namely its ability to operate effectively within international institutions that matter. Institutions may not be able to play the same role they have in the past in mitigating great power conflict and facilitating collective action to tackle shared problems. This is a major problem for Australia, which has benefited so much from a multilateral order that moderated the 'law of the jungle' nature of international relations and provided voice to smaller countries. We may well be moving towards a world in which competing great powers strive to shape the regional environment and check each other's aspirations; a world in which Australia's interests are met, or not, in the course of the fallout of these great power contests. The impending international environment demands that we develop a greater capacity for long-range thinking and planning. Long-term planning in foreign policy is different to that in other policy realms in which governments have much greater capacity to authoritatively set outcomes. In foreign policy, long-term planning must be oriented to achieving a mutual reconciliation between our core national interests and the flow of history decades into the future. It is not about fortune-telling. It is about thinking hard about how observable trends are likely to evolve and interact, how they may be subject to sudden disjunctures, and how different scenarios may impact on our security, prosperity and political values.

\section{Conclusion}

One of the unfortunate tendencies in the analysis of Australian foreign policy has been to polarise the regional and the global environment as competing foci for Australian foreign policy. For example, O'Neil claims that 'it has frequently been overlooked by those who should know better that the Asia-Pacific remains by far the single most important region in the international system for Australia' (O'Neil 2007, 539; see also Milner 2000). In contrast, Hugh Collins has observed that 'Australia is a country without a region. Its interests and identity cannot be enclosed within a consistent set of boundaries [because] the conditions of world order are the immediate conditions of Australian security and prosperity' (Collins 1985, 162. For an assessment of Australia's 'paradigm shift' in security thinking after 9/11, see Hirst 2007). Despite the contradiction between these claims, it is not the case that Australia can either choose between them or play a leading role at the global or the regional level. Our fate depends on being able to sustain a close security relationship with the United States, growing economic ties with China, plus good relations with Japan as well as Southeast Asia. As the controversy in early 2008 over Kevin Rudd's apparent snub to Japan indicates, this juggling act is never easy. It is likely to become more difficult, not less, in the coming years. Fortunately, Australia has time on its side. There is little evidence, despite the rise of anti-Americanism in Australia and the region, that the United States is about to disengage (see Griffiths 2008, 100). Nor, despite the concern over its apparent decline in 'soft power', is there evidence that other potential great powers are actively attempting to balance the United States (Wesley 2007, 170). In this context, regional 'engagement' has to be considered against a background of changes to the balance of power at a global level as well as a regional level. Our paramount national interest is to exploit whatever opportunities 
that we can to ensure that those changes do not leave Australia dependent on the vicissitudes of good fortune. Unfortunately, Australia is yet to develop a capacity for strategic policymaking that would enable us to identify and shape those opportunities to our best advantage.

Martin Griffiths is Associate Professor, Department of International Business and Asian Studies, Griffith University. Michael Wesley is Executive Director of the Lowy Institute for International Policy, Sydney.

The authors are grateful to two anonymous reviewers for their comments on an earlier draft of this article. 


\section{References}

Acharya, A. and Goh, E. 2007. Reassessing Security Cooperation in the Asia-Pacific: Competition, Congruence and Transformation. Cambridge, MA: MIT Press.

Banlaoi, R. 2003. 'Southeast Asian Perspectives on the Rise of China: Regional Security after 9/11.’ Parameters 33(2): 98-107.

Bergsten, C. 2008. 'A Partnership of Equals.' Foreign Affairs 87(4): 57-69.

Bull, H. 1974. 'Australia and the Great Powers in Asia.' In Australia in World Affairs 1950-1955, eds G. Greenwood and N. Harper. Melbourne: F. W. Cheshire.

Burke. A. and McDonald, M. 2007. Critical Security in the Asia-Pacific. Manchester: Manchester University Press.

Calder, K. and Fukuyama, F. 2008. East Asian Multilateralism: Prospects for Regional Stability. Baltimore, MD: Johns Hopkins University Press.

Casey, R. 1953. Commonwealth Parliamentary Debates, House of Representatives 27 November.

Collins, H. 1985. 'Political Ideology in Australia: The Distinctiveness of a Benthamite Society.' In Australia: The Daedalus Symposium, ed S. Graubard. Sydney: Angus \& Robertson.

Conley, T. 2002. 'Globalisation as Constraint and Opportunity: Reconceptualising Policy Capacity in Australia.’ Global Society 16(4): 377-399.

Drysdale, P. and Lu, W. 1996. 'Australia's Export Performance in East Asia', Pacific Economic Paper No. 259, Canberra: Australia-Japan Research Centre.

Dupont, A. 2001. East Asia Imperilled: Transnational Threats to Security. New York: Cambridge University Press.

Evans, G. 1993. Cooperating for Peace: The Global Agenda for the 1990s and Beyond. Sydney: Allen and Unwin.

Fitzgerald, C.P. 1957. 'Australia and Asia.' In Australia in World Affairs 1950-1955, eds G. Greenwood and N. Harper. Melbourne: F. W. Cheshire.

FitzGerald, S. 1997. Is Australia an Asian Country? Sydney: Allen and Unwin.

Garnaut, R. 1989. Australia and the Northeast Asian Ascendancy, Canberra: AGPS.

Garnaut, R. 1999. 'APEC Ideas and Reality: History and Prospects', paper presented to the $25^{\text {th }}$ Pacific Trade and Development Conference, Osaka, 16-18 July.

Gorgao, P. 2003. 'Australia's Dilemma between Geography and History: How Consolidated is Engagement with Asia?' International Relations of the Asia-Pacific 3(1): 179-196.

Grey, J. 1999. A Military History of Australia. Melbourne: Cambridge University

Press.

Griffiths, M. 2008. 'Ambivalent Engagement: The United States and International

Organization.’ In The United States and Canada 2008, ed J. O’Brien. London:

Routledge.

Gyngell, A. 2007. 'Muscling up APEC.' The Diplomat (September/October). URL: <http://www.the-diplomat.com/article.aspx?aeid=3303>. Consulted 18 July 2008.

Gyngell, A. and Wesley, M. 2007. Making Australian Foreign Policy. Melbourne: Cambridge University Press.

Haacke, J. 2003. ASEAN's Diplomatic and Security Culture. London: Routledge.

Heazle, M. and Knight, N. Eds. 2007. China-Japan Relations in the Twenty-First Century: Creating a Future Past. Cheltenham: Edward Elgar.

Hirst, C. 2007. 'The Paradigm Shift: 11 September and Australia's Strategic Reformation.’ Australian Journal of International Affairs 61(2): 175-92. 
Horne, D. 1965. The Lucky Country: Australia in the 1960s. London: Penquin.

Howard, J. 1999. Commonwealth Parliamentary Debates, House of Representatives, 21 September.

Keating, P. 1996. Australia, Asia and the New Regionalism. Singapore: Institute of Southeast Asian Studies.

Kelly, P. 2000. 'One Club We Won’t be Joining.' The Australian, 26 April.

Kent, A. 2002. 'China's International Socialisation: The Role of International Organisations.' Global Governance, 8(3): 343-64.

Langlois, A. 2001. The Politics of Justice and Human Rights: Southeast Asia and Universalist Theory. Cambridge: Cambridge University Press.

Lyon, R. 2008. 'All our Challenges are Long-Term.' The Australian 12-13 July.

Malik, M. 2006. 'China and the East Asian Summit: More Discord than Accord.' Honolulu, HI: Asia-Pacific Center for Security Studies Occasional Paper. URL: $<$ http://www.apcss.org/Publications/APSSS/ChinaandEastAsiaSummit.pdf $>$.

Consulted 1 September 2008.

Martin Jones, D. and Smith, M. 2006. ASEAN and East Asian International Relations: Regional Delusion. Cheltenham: Edward Elgar.

Miller, J. 2004. 'The Roots and Implications of East Asian Regionalism.' Honolulu, HI: Asia-Pacific Center for Security Studies Occasional Paper. URL: $<$ http://www.apcss.org/Publications/Ocasional\%20Papers/A_PStudiesR1.Sept.2004.p df $>$. Consulted 1 September 2008.

Milner, A. 'What's Left of Engagement with Asia?' Australian Journal of International Affairs 54(2): 177-184.

Morse, R. 1988. 'Energy.' In Technology in Australia 1788-1988, Melbourne: Australian Academy of Technology, Science and Engineering.

O’Neil, A. 2007. 'Book Review.' Australian Journal of Political Science 42(3): 539540.

Robertson, J. 1988. 'The Distant War: Australia and Imperial Defence, 1919-1941.’ In Australia in Two Centuries of War and Peace, eds M. McKernan and M. Browne.

Canberra: Australian War Memorial in Association with Allen and Unwin.

Smith, G. and Lowe, D. 2005. 'Howard, Downer and the Liberals' Realist Tradition.' Australian Journal of Politics and History 51(3): 459-472.

Soesastro, H. 1994. 'Pacific Economic Cooperation: The History of an Idea.' In Asia Pacific Regionalism: Readings in International Economic Relations, eds R. Garnaut and P. Drysdale. Sydney: HarperEducational.

Webber, D. 2001. 'Two Funerals and a Wedding? The Ups and Downs of Regionalism in East Asia and the Asia-Pacific after the Asian Crisis.' The Pacific Review 14(3): 339-72.

Wesley, M. 2007. The Howard Paradox. Sydney: ABC Books.

Wesley, M. 2005. 'It's Time to Scrap the NPT', Australian Journal of International Affairs, Vol. 59(2): 283-99.

World Trade Organization. 2007. International Trade Statistics 2007. Geneva: WTO. URL: <http://www.wto.org/english/res_e/statis_e/statis_e.htm>. Consulted 1 September 2008. 